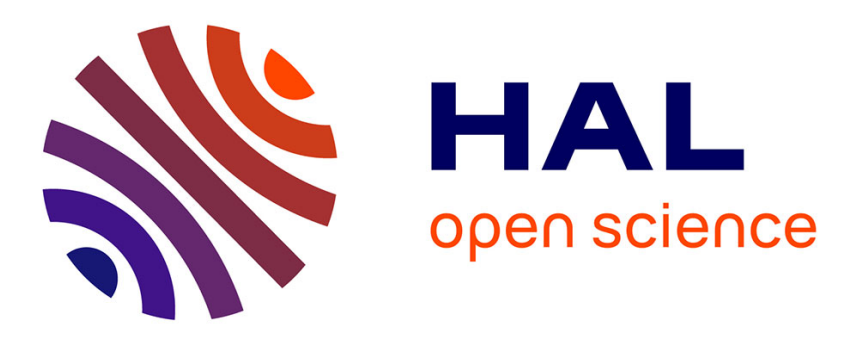

\title{
Inability of Near Infrared Reflectance Spectroscopy (NIRS) to identify belowground earthworm casts in no-tillage soil
}

Nicolas Bottinelli, Yvan Capowiez, Vincent Hallaire, Jacques Ranger, P. Jouquet

\section{To cite this version:}

Nicolas Bottinelli, Yvan Capowiez, Vincent Hallaire, Jacques Ranger, P. Jouquet. Inability of Near Infrared Reflectance Spectroscopy (NIRS) to identify belowground earthworm casts in no-tillage soil. Applied Soil Ecology, 2013, 70, pp.57- 61. 10.1016/j.apsoil.2013.04.006 . hal-01209122

\section{HAL Id: hal-01209122 \\ https://hal.science/hal-01209122}

Submitted on 28 May 2020

HAL is a multi-disciplinary open access archive for the deposit and dissemination of scientific research documents, whether they are published or not. The documents may come from teaching and research institutions in France or abroad, or from public or private research centers.
L'archive ouverte pluridisciplinaire HAL, est destinée au dépôt et à la diffusion de documents scientifiques de niveau recherche, publiés ou non, émanant des établissements d'enseignement et de recherche français ou étrangers, des laboratoires publics ou privés. 


\title{
Inability of Near Infrared Reflectance Spectroscopy (NIRS) to identify belowground earthworm casts in no-tillage soil
}

\author{
N. Bottinelli ${ }^{\mathrm{a}, *}$, Y. Capowiez $^{\mathrm{b}}$, V. Hallaire ${ }^{\mathrm{c}, \mathrm{d}}$, J. Ranger $^{\mathrm{a}}$, P. Jouquet $^{\mathrm{e}}$ \\ a INRA, UR1138 INRA, Biogéochimie des Ecosystèmes Forestiers, F-54280 Champenoux, France \\ ${ }^{\mathrm{b}}$ INRA, UR 1115 Plantes et Systèmes Horticoles, Domaine Saint Paul, 84914 Avignon Cedex 09, France \\ ' INRA, UMR1069 Sol Agro et hydrosystème Spatialisation, F-35000 Rennes, France \\ d Agrocampus Ouest, F-35000 Rennes, France \\ e IRD, UMR 211 BIOEMCO (CNRS, IRD, ENS, UPMC, UPEC, AgroParisTech), 32 Avenue H. Varagnat, 93143 Bondy Cedex, France
}

Keywords:

Earthworm casts

Drilosphere

Soil spatial organisation

Control reference soil

\begin{abstract}
A B S T R A C T
Several studies have emphasised the ability of Near Infrared Reflectance Spectroscopy (NIRS) to identify surface earthworm casts in the field. However, less is known about casts deposited within the soil, which usually represent the majority found in the field. This study tested the ability of NIRS to identify belowground casts in agricultural systems. Casts and surrounding soils were sampled at depths of $20-30 \mathrm{~cm}$ in a loamy soil under no tillage for 12 years. To distinguish different types of cast, sizes and orientations relative to the horizontal plane were measured. NIRS analyses and analyses of carbon and nitrogen content were also performed to compare casts to surrounding soils. Casts were classified into 4 size classes, with no preferential orientation. Cast carbon and nitrogen content were not influenced by their size and did not differ from surrounding soils. PCAs performed on the NIRS data did not allow casts to be differentiated from surrounding soils, regardless of size class. However, soil aggregates were clearly differentiated probably due to their spatial distribution in the soil. Although this study did not identify specific NIRS signatures for casts, it shows the utility of this method to investigate the origin of the soil consumed by earthworms. In our case, NIRS analyses suggest that the high bulk density of the soil $\left(1.42 \mathrm{~g} \mathrm{~cm}^{-3}\right)$ forced ingestion by endogeic earthworms, simply to move around, without preferential selection for organic matter. Consequently, their casts were deposited a few $\mathrm{mm}$ from where they had ingested soil with similar organic matter quality.
\end{abstract}

\section{Introduction}

As an organised system, any modification of soil structure results, though not exclusively, from the activity of plant roots and soil fauna. Among the main regulators of soil structure are earthworms, often called 'soil engineers' due to their high abundance and activity in soils and their ability to create galleries and soil organo-mineral aggregates called 'casts' (Lee and Foster, 1991; Jouquet et al., 2006). Earthworms have been the focus of many studies since the pioneering work of Darwin (1881). Nevertheless, the influence of earthworms on soil functioning remains difficult to quantify, mainly because of the difficulty in assessing the dynamics of earthworm biostructures in the field. Recent studies suggest that the specific composition of organic matter in earthworm casts (e.g.

\footnotetext{
* Corresponding author at: UR1138 INRA, Biogéochimie des Ecosystèmes Forestiers, rue d'Amance, 54280 Champenoux, France. Tel.: +33 3833941 09; fax: +33 383394076 .

E-mail address: nicobottinelli86@hotmail.com (N. Bottinelli).
}

resulting from the selective ingestion of organic matter followed by multiple transformations during transit) analysed by Near Infrared Reflectance Spectroscopy (NIRS) could allow significant progress on this topic (Hedde et al., 2005; Vélasquez et al., 2007; Jouquet et al., 2009; Zhang et al., 2009; Cécillon et al., 2010; Jouquet et al., 2010, 2011; Zangerlé et al., 2011).

NIRS is a rapid and reproducible analytical method that measures the intensity of the absorption of near-infrared light of a sample. The resulting spectra give unique chemical fingerprints, which have been used to differentiate earthworm-impacted soils from surrounding soil that has not been recently ingested, usually considered as reference. The use of NIRS to differentiate earthworm casts from surrounding soil has been used mainly for surface soils in the field (Hedde et al., 2005; Vélasquez et al., 2007; Jouquet et al., 2009,2010 ) or on earthworm casts produced in simplified systems in laboratory conditions (Zhang et al., 2009; Jouquet et al., 2011; Zangerlé et al., 2011). Less is known, however, about the relevance of this method for differentiating subsurface earthworm casts in the field (Cécillon et al., 2010), which can represent a large proportion of casts (especially for endogeic species) (Whalen et al., 2004; 
Version définitive du manuscrit publiée dans / Final version of the manuscript published in :

Applied Soil Ecology (2013), Vol. 70, p. 57-61, DOI: 10.1016/j.apsoil.2013.04.006

Journal homepage: http://www.elsevier.com/locate/apsoil
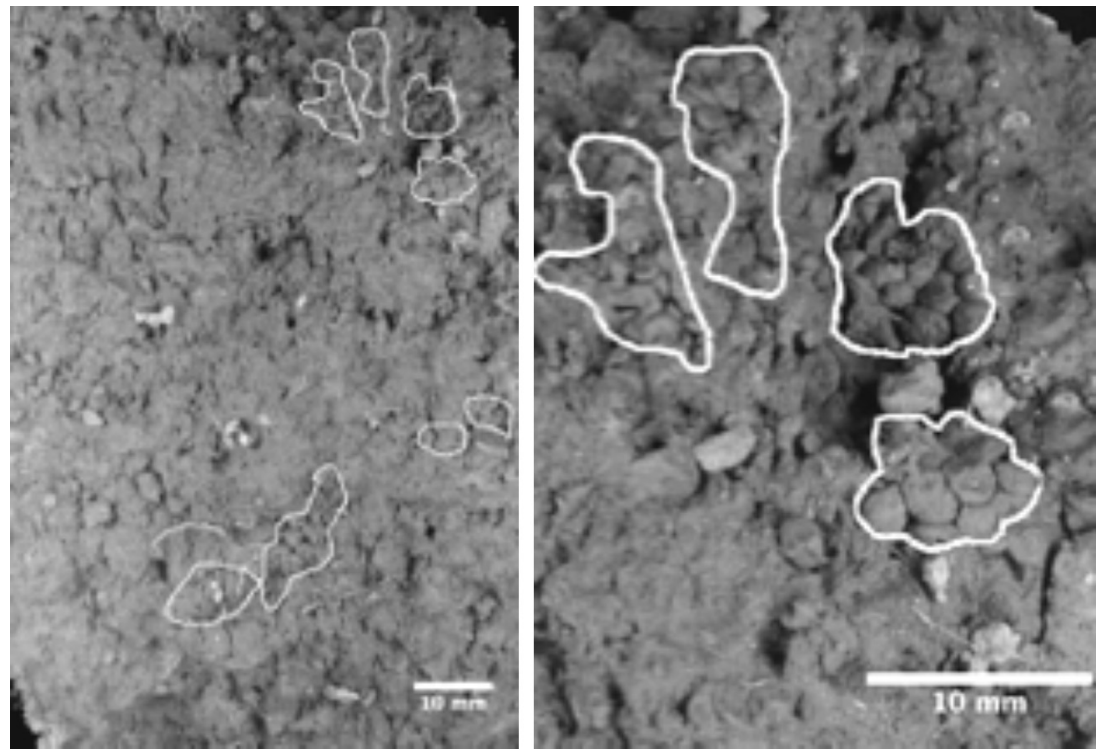

Fig. 1. Example of a vertically oriented soil block sampled for analyses. Clusters of casts are outlined in white.

Bottinelli et al., 2010b; Capowiez et al., 2011), since their origins and dynamics are by nature more complex than those recreated in laboratory conditions or described on the soil surface.

The objective of this study was therefore to test the relevance of NIRS to differentiate belowground casts in the field. We hypothesised that NIRS signatures could differentiate earthworm casts from surrounding soil. Casts and surrounding soils were sampled at depths of $20-30 \mathrm{~cm}$ in soil under no tillage for 12 years. NIRS analyses and analyses of carbon and nitrogen content were performed to compare casts of different types (e.g., from different sizes and orientations) to surrounding soils lacking visible earthworm activity.

\section{Material and methods}

The study was performed in November 2011 at the Kerguéhennec Experimental Station located in western France $\left(47^{\circ} 52^{\prime} 58 \mathrm{~N}\right.$, $2^{\circ} 43^{\prime} 59 \mathrm{~W}$ ). The climate is temperate oceanic, with a mean annual precipitation of $890 \mathrm{~mm}$. The soil is classified as a Humic Cambisol (FAO/WRB classification) with, at a depth of $20-30 \mathrm{~cm}$, a loamy texture ( $17 \%$ clay, $42 \%$ silt, $42 \%$ sand), $2.0 \%$ of organic carbon content and a bulk density of $1.42 \mathrm{~g} \mathrm{~cm}^{-3}$ (Viaud et al., 2011), with fertilisation by poultry manure and no tillage. More details of management practices are described in Viaud et al. (2011). During the study, the field was planted with rapeseed as a cover crop in the crop sequence wheat/catch crop/maize. In May 2007, earthworms had been sampled using formaldehyde (Bouché, 1977) coupled with a hand sorting method (Cluzeau et al., 1999) and identified using Bouché's (1972) key in laboratory. Nine species were found: four endogeic species (Aporrectodea caliginosa, Allolobophora icterica, Allolobophora rosea and Allolobophora chlorotica typica), two anecic species (Lumbricus terrestris and Aporrectodea giardi) and three epigeic species (Dendrobaena mammalis, Lumbricus rubellus castaneus and L. rubellus). In total, earthworm abundance was 489 individuals. $\mathrm{m}^{-2}$ and dominant species were A. caliginosa (44\%), $L$. terrestris (20\%) and A. icterica (18\%).

\subsection{Soil sampling and preparation}

Because roots of rapeseed were abundant close to the surface which impeded the excavation of intact blocks, sampling was performed in the $20-30 \mathrm{~cm}$ soil layer. Twenty-three soil blocks $(15 \mathrm{~cm}$ long $\times 10 \mathrm{~cm}$ wide) were collected manually from a single soil profile $5 \mathrm{~m}$ long. Blocks were oriented, labelled and carefully transported to the laboratory. Thereafter, blocks were air-dried and photographed with a Nikon D700 camera with a resolution of $30 \mu \mathrm{m}$ per pixel. On an image of each block, clusters of casts were meticulously outlined and manually labelled (Fig. 1). In total, 109 clusters were identified for analysis.

\subsection{Types of casts}

To identify different types of casts, the diameter of individual casts and the orientation of cast clusters (i.e., the angle between a cluster's primary axis and a line parallel to the $x$-axis of the image) were measured with imageJ software. It is likely that different cast sizes and orientation of cast clusters could be related to different species or development stages of earthworms that produced them. Five individual casts were randomly selected per cluster and their size measured. The size distribution was bimodal, with two peaks from $1.4-1.8 \mathrm{~mm}$ to $1.8-2.4 \mathrm{~mm}$ (Fig. 2), which represented $85 \%$

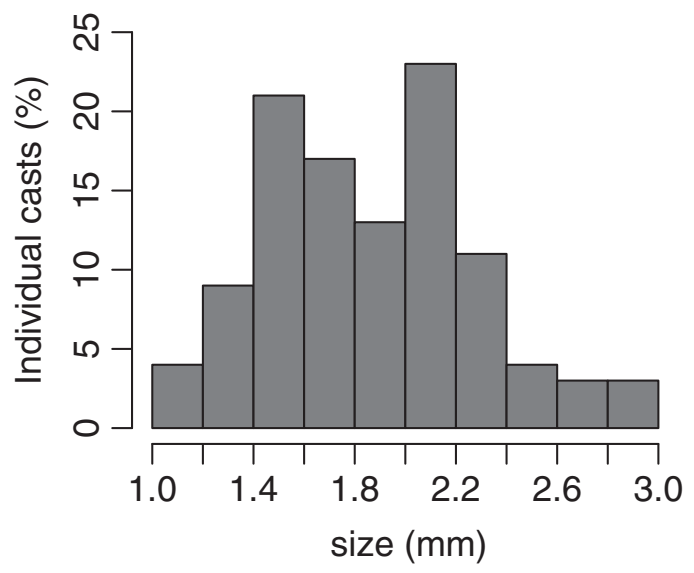

Fig. 2. Size distribution of casts sampled in no-tillage with poultry manure fertilisation between 20 and $30 \mathrm{~cm}$ depth. 
Version définitive du manuscrit publiée dans / Final version of the manuscript published in :

Applied Soil Ecology (2013), Vol. 70, p. 57-61, DOI: 10.1016/j.apsoil.2013.04.006

Journal homepage: http://www.elsevier.com/locate/apsoil

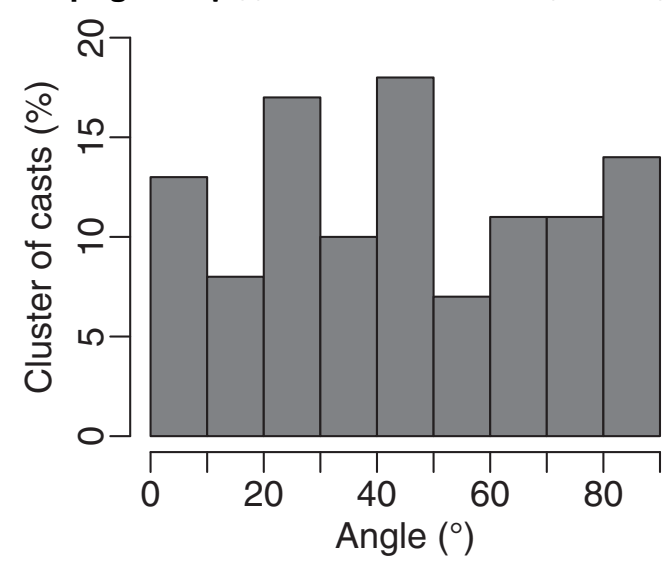

Fig. 3. Distribution of cast clusters according to their orientation with the horizontal plane. 0 and 90 degree represent casts oriented horizontally and vertically, respectively. Casts were sampled in no-tillage with poultry manure fertilisation between 20 and $30 \mathrm{~cm}$ depth.

of all casts. The orientation of clusters showed no particular distribution (Fig. 3), demonstrating that the orientation of clusters was random. Thus, cast types were classified only by four cast sizes (1-1.4, 1.4-1.8, 1.8-2.4 and $2.4-3 \mathrm{~mm})$ in the subsequent chemical analyses.

\subsection{Chemical analyses}

Chemical analyses were measured on cast clusters and surrounding soils (e.g. soil collected few $\mathrm{mm}$ from casts and lacking visible earthworm activity with the naked eye). The carbon and nitrogen contents of casts and surrounding soils were measured in three replicates for the four size classes with a CHN analyser (Elementar Vario EL III). NIRS analyses were performed on casts and adjacent surrounding soil on soil blocks without any pre-treatment ('unground' samples) or extracted from blocks and manually ground to a fine powder $(\sim 0.1-0.5 \mathrm{~g}<200 \mu \mathrm{m})$ ('ground' samples). Because some clusters were too small to provide enough material or because surrounding soil without earthworm features was not clearly identified, only 62 and 55 clusters were analysed in unground and ground samples, respectively. Samples were scanned with a spectrometer (Matrix-F, Bruker) in the $1100-2500 \mathrm{~nm}$ spectral range. The reflectance measurements were made at $0.5 \mathrm{~nm}$ intervals. Reflectance $(R)$ was converted to absorbance $(A)$ using the equation: $A=\log (1 / R)$ and further transformed to second derivative according to general procedures recommended to remove baseline shifts and separate overlapping absorption (Cécillon et al., 2010). Finally, average values were calculated for $20 \mathrm{~nm}$ intervals in order to reduce the number of variables processed.

\subsection{Statistical analysis}

All statistical calculations were carried out using $\mathrm{R}$ software. Differences in carbon and nitrogen contents between casts and surrounding soils were tested using multiple comparison Kruskal-Wallis tests with R's 'pgirmess' library. Principal component analyses (PCA) were performed from the NIRS data with R's 'ade4' library. Data corresponded to a matrix of 68 wavelengths $\times 124$ objects for the unground samples and 68 wavelengths $\times 110$ objects for the ground samples. Differences in PCA coordinates between casts and surrounding soils were tested using permutation tests. Differences were evaluated at the 0.05 probability level of significance.
Table 1

Mean (standard deviation) carbon and nitrogen contents of casts in the 1-1.4, $1.4-1.8,1.8-2.4$ and $2.4-3 \mathrm{~mm}$ size classes and surrounding soils.

\begin{tabular}{llll}
\hline Size $(\mathrm{mm})$ & Type & $\mathrm{C}(\%)$ & $\mathrm{N}(\%)$ \\
\hline \multirow{2}{*}{$1.0-1.4$} & Cast & $1.9(0.5)$ & $0.2(0.1)$ \\
& Soil & $1.5(0.4)$ & $0.2(0.0)$ \\
$1.4-1.8$ & Cast & $1.9(0.0)$ & $0.2(0.0)$ \\
& Soil & $1.8(0.0)$ & $0.2(0.0)$ \\
$1.8-2.4$ & Cast & $2.1(0.6)$ & $0.2(0.1)$ \\
& Soil & $1.9(0.2)$ & $0.2(0.0)$ \\
$2.4-3.0$ & Cast & $1.8(0.3)$ & $0.2(0.0)$ \\
& Soil & $1.8(0.0)$ & $0.2(0.0)$ \\
\hline
\end{tabular}

\section{Results}

The carbon and nitrogen contents of casts and surrounding soils were not statistically different regardless of cast size (Table 1 ), and values were similar among the 4 sizes considered $(P>0.05)$.

From the PCA of NIRS spectra, only 2 and 4 groups were observed in unground and ground samples, respectively (Fig. 4). For unground samples, separation mainly occurred along the first axis of the PCA, which explained $13 \%$ of the variability. For ground samples, aggregates were separated on the first and second axes, which explained 16 and $12 \%$, respectively. The groups separated, however, referred neither to aggregate origin or size, but seemed to result from natural soil heterogeneity. In the PCA, NIRS spectra of casts were always similar to those of their surrounding soils $(P>0.05$ for all sizes), whether unground or ground.
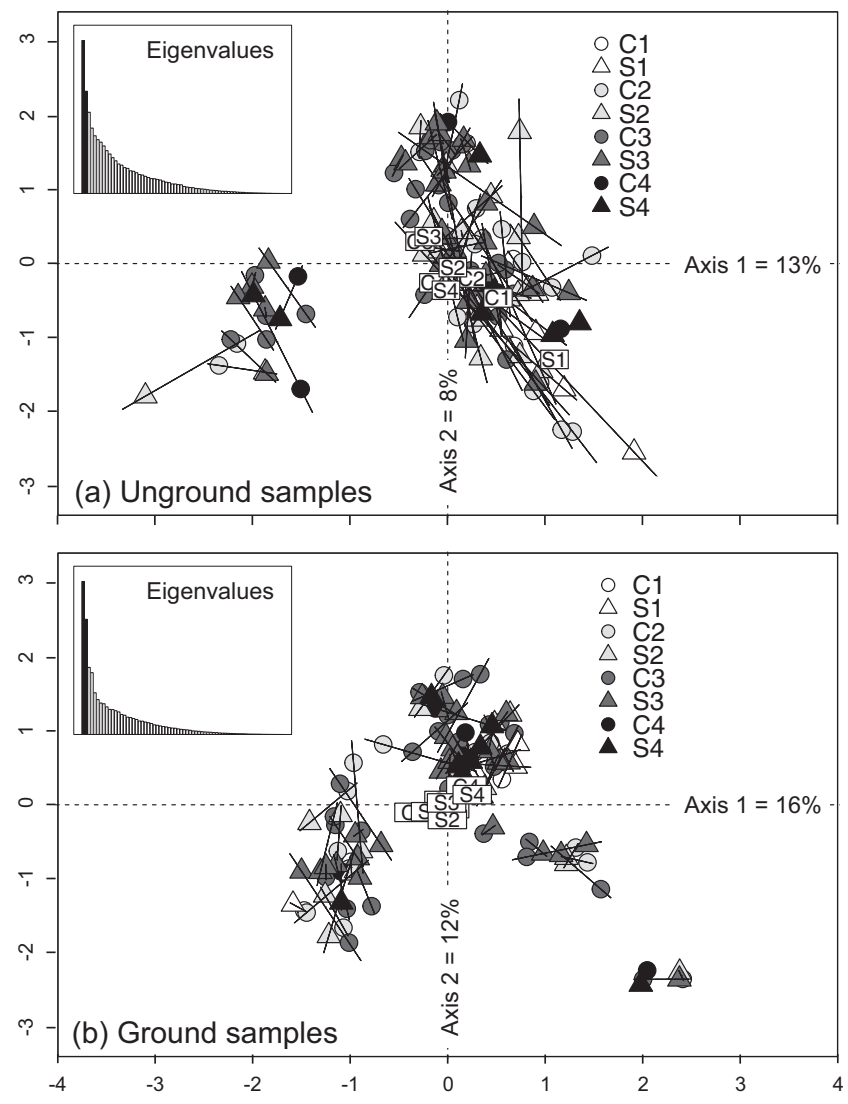

Fig. 4. PCA of NIRS spectra of casts (C) and surrounding soils (S) of (a) unground and (b) ground samples. Numbers indicate the four size classes of casts considered: (1) 1-1.4 mm, (2) 1.4-1.8 mm, (3) 1.8-2.4 mm and (4) 2.4-3 mm. Lines connect each cast cluster with its surrounding aggregates. Tags with group names represent the barycentre of each group. 
Version définitive du manuscrit publiée dans / Final version of the manuscript published in :

Applied Soil Ecology (2013), Vol. 70, p. 57-61, DOI: 10.1016/j.apsoil.2013.04.006

Journal homepage: http://www.elsevier.com/locate/apsoil

\section{Discussion}

\subsection{Origin of belowground earthworm casts}

Casts found within the soil are thought to be associated mainly with the casting activity of endogeic species. However, laboratory studies have shown that anecic species can also deposit casts within the soil without lining their burrows (Curry and Baker, 1998; Felten and Emmerling, 2009; Capowiez et al., 2011). To differentiate anecic from endogeic origins of casts, several criteria could be considered. First, burrows created by anecic species are mainly vertically to sub-vertically oriented, but those of endogeic species have no preferential orientation (Felten and Emmerling, 2009; Capowiez et al., 2011); therefore, clusters of casts may have a preferential orientation according to the type of earthworm. Second, adult anecic species are larger than adult endogeic species (Bouché, 1972; Pérès et al., 1998), meaning that their casts may be larger, too. Finally, anecic species select their food, which is richer in organic matter than that ingested by endogeic species (Curry and Schmidt, 2006). As a result, casts produced by anecic species generally have more organic matter than surrounding soils (Hedde et al., 2005; Jouquet et al., 2008), which is not the case for endogeic species, depending on soil properties (Barois et al., 1999; Bottinelli et al., 2010a).

In the present study, the orientation of cast clusters seemed to be random. Cast size ranged from 1 to $3 \mathrm{~mm}$, with most ranging from 1.8 to $2.4 \mathrm{~mm}$. Finally, the carbon and nitrogen contents were similar between casts and their surrounding soils, suggesting that earthworms did not select their food. All these results strongly suggest that casts found in the $20-30 \mathrm{~cm}$ soil layer were all produced by endogeic species, presumably A. caliginosa and/or A. icterica, which had previously been shown to represent 64 and $27 \%$ of the total abundance of endogeic earthworms, respectively. Because A. caliginosa and A. icterica are nearly a similar size at the study site, their casts probably have the same size. Hence, the 4 size classes of casts more likely reflect the development stage of these earthworms instead of the species.

\subsection{NIRS as a tool to differentiate endogeic earthworm casts in crop fields}

Grinding soil aggregates increased the number of groups differentiated from 2 to 4 , confirming the utility of extracting and grinding soil aggregates before measuring their NIRS signatures, as suggested by Brunet et al. (2007). It is likely that reflectance is influenced by the size of aggregates and that this effect is reduced by grinding. Differentiation of groups seemed to result from soil heterogeneity. NIRS fingerprints are known to be plot-dependent at ecosystem scales (Vélasquez et al., 2007; Cécillon et al., 2010), but at smaller scales, our study confirms the high spatial heterogeneity within soil (Tisdall and Oades, 1982; Young and Ritz, 1998; Young et al., 2008) and highlights the usefulness of NIRS to describe it (Patzold et al., 2008; Wielopolski et al., 2010).

Regardless of treatment, NIRS did not distinguish casts and their surrounding soils in this study, suggesting that NIRS is not always useful for differentiating recently emitted casts from their surrounding soils in the field. The similar NIRS signatures and carbon and nitrogen contents of casts and surrounding soils highlight that their quantity and quality of soil organic matter was similar. These results may be explained by (i) the high soil bulk density $\left(1.42 \mathrm{~g} \mathrm{~cm}^{-3}\right)$, which may have forced earthworms to ingest soil simply to move around (Whalley et al., 1995) and did not allow them to select their food. As a result, casts were deposited a few $\mathrm{mm}$ from where they were ingested and had similar soil organic matter content and quality as surrounding soils. In addition, (ii) the surrounding soil may not have represented a true control, instead consisting mainly of weathered casts not discernible with the naked eye, since this soil is highly bioturbated (Bottinelli et al., in press). Finally, (iii) earthworms may have influenced the NIRS signature of the surrounding soil by leaching nutrients, which may have extended the limit of the drilosphere around the casts (Jouquet et al., 2011). Hence, the absence of an influence of casting activity on NIRS fingerprints was not completely surprising in this context. These results, however, contradict previous studies performed in laboratory conditions (Zhang et al., 2009; Zangerlé et al., 2011) that found specific NIRS signatures for casts. Differences between these experiments and ours may be explained by the fact that the laboratory casts (i) were enriched in organic matter since endogeic earthworms were fed with leaf litter and (ii) were compared to a non-ingested soil, sampled from microcosms without earthworms (Jouquet et al., 2011). It is evident that these laboratory conditions did not reflect the complex conditions of our field study. Surprisingly, our results did not confirm those of Cécillon et al. (2010), who identified specific NIRS signatures of belowground casts when compared to physicogenic aggregates sampled in the Ah horizons of three mountain forest ecosystems. These different results may be due to (i) higher soil organic matter content and macroporosity of the soils sampled and (ii) different earthworm species producing belowground casts.

NIRS was unable to identify casts produced by juveniles or adults of A. caliginosa or A. icterica. In addition, the carbon and nitrogen contents of casts were not statistically different. Hence, our study does not confirm the ability of NIRS to differentiate casts produced by different endogeic species, as shown by Zangerlé et al. (2011) in laboratory conditions.

\section{Conclusion}

In conclusion, it appears that the usefulness of using NIRS to differentiate cast aggregation may be context-dependent. Nonetheless, though NIRS could not differentiate earthworm casts from their surrounding soil environment, it pinpointed strategies that earthworms, probably the endogeic A. caliginosa and/or A. icterica may use to move, feed and produce casts in the field.

\section{Acknowledgements}

We thank the personnel of the Brittany Chamber of Agriculture, in particular Djilali Heddadj and Patrice Cotinet, who helped perform this work on the Kerguéhennec research site. We are grateful to Patrick Lavelle for constructive discussion, Lauric Cécillon for his help in data analyses and Michael and Michelle Corson for useful English corrections on the manuscript.

\section{References}

Barois, I., Lavelle, P., Brossard, M., Tondoh, J., Martinez, M.A., Rossi, J.P., Senapati, B.K., Angeles, A., Fragoso, C., Jimenez, J.J., Decaens, T., Lattaud, C., Kanyonyo, J., Blanchart, E., Chapuis, L., Brown, G., Moreno, A., 1999. Ecology of earthworm species with large environmental tolerance and/or extended distributions. In: Lavelle, P., Brussaard, L., Hendrix, P. (Eds.), Earthworm Management in Tropical Agroecosystems. CAB International, Wallingford, UK.

Bottinelli, N., Hallaire, V., Menasseri-Aubry, S., Le Guillou, C., Cluzeau, D., 2010a. Abundance and stability of belowground earthworm casts influenced by tillage intensity and depth. Soil Tillage Res. 106, 263-267.

Bottinelli, N., Henry-des-Tureaux, T., Hallaire, V., Mathieu, J., Benard, Y., Tran, T.D., Jouquet, P., 2010b. Earthworms accelerate soil porosity turnover under watering conditions. Geoderma 156, 43-47.

Bottinelli, N., Menasseri-Aubry, S., Cluzeau, D., Hallaire, V., in press. Response of soil structure and hydraulic conductivity to reduced tillage and animal manure in a temperate loamy soil. Soil Use Manag., http://dx.doi.org/10.1111/sum.12049

Bouché, M.B., 1972. Lombriciens de France. Ecologie et systématique, Paris.

Bouché, M.B., 1977. Stratégies lombriciennes. In: Lohm, U., Persson, T. (Eds.), Soil Organisms and Components of Ecosystems. Ecology Bulletin/NFR, Stockholm.

Brunet, D., Barthes, B.G., Chotte, J.L., Feller, C., 2007. Determination of carbon and nitrogen contents in Alfisols, Oxisols and Ultisols from Africa and Brazil using NIRS analysis: effects of sample grinding and set heterogeneity. Geoderma 139, 106-117. 
Version définitive du manuscrit publiée dans / Final version of the manuscript published in :

Applied Soil Ecology (2013), Vol. 70, p. 57-61, DOI: 10.1016/j.apsoil.2013.04.006

\section{Journal homepage: http://www.elsevier.com/locate/apsoil}

Capowiez, Y., Sammartino, S., Michel, E., 2011. Using X-ray tomography to quantify earthworm bioturbation non-destructively in repacked soil cores. Geoderma $162,124-131$.

Cécillon, L., de Mello, N.A., De Danieli, S., Brun, J.J., 2010. Soil macroaggregate dynamics in a mountain spatial climate gradient. Biogeochemistry 97, 31-43.

Cluzeau, D., Cannavacciulo, M., Pérès, G., 1999. Indicateurs macrobiologiques des sols: les lombriciens-Méthode d'échantillonnage dans les agrosystèmes en zone tempérée. In: Colloque Euroviti 1999-12ème Colloque Viticole et Enologique, ITV Paris, pp. 25-35.

Curry, J.P., Baker, G.H., 1998. Cast production and soil turnover by earthworms in soil cores from South Australian pastures. Pedobiologia 42, 283-287.

Curry, J.P., Schmidt, O., 2006. The feeding ecology of earthworms - a review. Pedobiologia $50,463-477$.

Darwin, C., 1881. The Formation of Vegetable Mould Through the Action of Worms with Some Observations on Their Habits. John Murray, London.

Felten, D., Emmerling, C., 2009. Earthworm burrowing behaviour in 2D terraria with single- and multi-species assemblages. Biol. Fertil. Soils 45, 789-797.

Hedde, M., Lavelle, P., Joffre, R., Jimenez, J.J., Decaens, T., 2005. Specific functional signature in soil macro-invertebrate biostructures. Funct. Ecol. 19, 785-793.

Jouquet, P., Dauber, J., Lagerlof, J., Lavelle, P., Lepage, M., 2006. Soil invertebrates as ecosystem engineers. Intended and accidental effects on soil and feedback loops. Appl. Soil Ecol. 32, 153-164.

Jouquet, P., Bottinelli, N., Podwojewski, P., Hallaire, V., Duc, T.T., 2008. Chemical and physical properties of earthworm casts as compared to bulk soil under a range of different land-use systems in Vietnam. Geoderma 146, 231-238.

Jouquet, P., Zangerle, A., Rumpel, C., Brunet, D., Bottinelli, N., Duc, T.T., 2009. Relevance and limitations of biogenic and physicogenic classification: a comparison of approaches for differentiating the origin of soil aggregates. Eur. J. Soil Sci. 60, 1117-1125.

Jouquet, P., Henry-des-Tureaux, T., Mathieu, J., Thuy, D.T., Toan, T.D., Orange, D., 2010. Utilization of near infrared reflectance spectroscopy (NIRS) to quantify the impact of earthworms on soil and carbon erosion in steep slope ecosystem A study case in Northern Vietnam. Catena 81, 113-116.

Jouquet, P., Huchet, G., Bottinelli, N., Thu, T.D., 2011. 2011. What are the limits of the drilosphere? An incubation experiment using Metaphire posthuma. Pedobiologia 54, S113-S117, Supplement.
Lee, K.E., Foster, R.C., 1991. Soil fauna and soil structure. Aust. J. Soil Res. 29, 745-775 Patzold, S., Mertens, F.M., Bornemann, L., Koleczek, B., Franke, J., Feilhauer, H., Welp, G., 2008. Soil heterogeneity at the field scale: a challenge for precision crop protection. Precision Agric. 9, 367-390.

Pérès, G., Cluzeau, D., Curmi, P., Hallaire, V., 1998. Earthworm activity and soil structure changes due to organic enrichments in vineyard systems. Biol. Fertil. Soils 27, 417-424.

Tisdall, J.M., Oades, J.M., 1982. Organic matter and water-stable aggregates in soils J. Soil. Sci. 33, 141-163.

Vélasquez, E., Pelosi, C., Brunet, D., Grimaldi, M., Martins, M., Rendeiro, A.C., Barrios, E., Lavelle, P., 2007. This ped is my ped: visual separation and near infrared spectra allow determination of the origins of soil macroaggregates. Pedobiologia $51,75-87$.

Viaud, V., Angers, D.A., Parnaudeau, V., Morvan, T., Aubry, S.M., 2011. Response of organic matter to reduced tillage and animal manure in a temperate loamy soil. Soil Use Manag. 27, 84-93.

Whalen, J., Sampedro, L., Waheed, T., 2004. Quantifying surface and subsurface cast production by earthworms under controlled laboratory conditions. Biol. Fertil. Soils 39, 287-291.

Whalley, W.R., Dumitru, E., Dexter, A.R., 1995. Biological effects of soil compaction. Soil Tillage Res. 35, 53-68.

Wielopolski, L., Johnsen, K., Zhang, Y., 2010. Soil analysis based on samples withdrawn from different volumes: correlation versus calibration. Soil Sci. Soc. Am. J. 74, 812-819.

Young, I.M., Crawford, J.W., Nunan, N., Otten, W., Spiers, A., 2008. Microbial distribution in soils: physics and scaling. In: Sparks, D.L. (Ed.), Advances in Agronomy. Elsevier Academic Press, San Diego, pp. 81-121.

Young, I.M., Ritz, K., 1998. Can there be a contemporary ecological dimension to soil biology without a habitat? Discussion. Soil Biol. Biochem. 30, 1229-1232.

Zangerlé, A., Pando, A., Lavelle, P., 2011. Do earthworms and roots cooperate to build soil macroaggregates? A microcosm experiment. Geoderma 167-168, 303-309.

Zhang, C., Langlest, R., Velasquez, E., Pando, A., Brunet, D., Dai, J., Lavelle, P., 2009. Cast production and NIR spectral signatures of Aporrectodea caliginosa fed soil with different amounts of half-decomposed Populus nigra litter. Biol. Fertil. Soils $45,839-844$. 